\title{
Measurement of androgen receptor expression in adult liver, fetal liver, and Hep-G2 cells by the polymerase chain reaction
}

\author{
A P Stubbs, J L Engelman, J I H Walker, P Faik, G M Murphy, M L Wilkinson
}

\begin{abstract}
Hepatocellular carcinoma is the most commonly fatal malignant tumour worldwide. The role of androgen receptors, which have been found in hepatocellular carcinoma, is controversial. Sequence specific polymerase chain reaction (PCR) was used to quantify, for the first time, the expression of androgen receptor in four adult liver biopsy specimens (HL-A to HL-D), fetal liver, and Hep-G2 cells. The measurement of androgen receptor is expressed as a ratio (androgen receptor: $\beta$ actin) of the value of androgen receptor to the value of a control gene, $\beta$-actin. The value of the androgen receptor: $\beta$-actin ratios for $H L$ A, HL-B, HL-C, HL-D, fetal liver, and Hep-G2 were $0.37,0.86,0.37,0.44,0.87$, and 0.66 respectively. To verify sequence specific amplification of the androgen receptor, the PCR androgen receptor fragment was sequenced. The resultant sequence data for both strands of the double stranded PCR androgen receptor fragment had $100 \%$ similarity with the published androgen receptor mRNA sequence (complete codons).

(Gut 1994; 35: 683-686)
\end{abstract}

The presence of androgen receptor in normal liver is controversial ${ }^{1}$ although its presence in hepatocellular carcinoma is thought to confer androgen responsiveness on this tumour. ${ }^{23}$ The detection of androgen receptor has depended on ligand binding assays, which are inaccurate and insensitive because of a labile receptor protein and low values of androgen receptor expression. The recent cloning of the androgen receptor and the subsequently derived sequence data have made it possible to prepare synthetic oligonucleotide probes to the receptor, ${ }^{4}$ and for these to be used as primers in a polymerase chain reaction (PCR). Using this approach androgen receptor expression has been detected in tissue resected from patients with hepatocellular carcinoma and in surrounding non-cancerous tissues and in one hepatoma cell line. ${ }^{5}$ No quantitative data have been presented, however, and androgen receptor mRNA in non-cirrhotic, non-malignant liver has not been determined. Similarly, the presence of androgen receptor in fetal liver tissue has yet to be determined, but it is known that the hepatic imprinting that occurs during the late period of organogenesis results in sexual dimorphism. ${ }^{6}$ We have used expression of the $\beta$-actin gene to provide a basis for comparison of androgen receptor mRNA determined by PCR. We have thus measured androgen receptor mRNA in adult liver tissue with minor abnor- malities (non-cirrhotic, non-malignant), in fetal liver tissue, and in Hep-G2 cells.

\section{Methods}

\section{TISSUE ACQUISITION}

Liver biopsy specimens were obtained by percutaneous biopsy using a Menghini needle technique.

These specimens were obtained - HL-A female (63 years): primary biliary cirrhosis (stage 2 histologically); HL-B female (40 years): mild non-specific changes perhaps related to alcohol; HL-C male (66 years): chronic persistent hepatitis - in association with thyrotoxicosis; HL-D female (48 years): fatty liver; fetal liver male: eight weeks gestation; Hep-G2 male: hepatoblastoma cell line cultured in Dulbecco's modified Eagle's medium supplemented with $10 \%$ fetal calf serum at $5 \% \mathrm{CO}_{2}$ and $95 \%$ humidity.

PREPARATION OF TOTAL RNA

Total RNA, from human liver (HL-A to HL-D) biopsy specimens, fetal liver, and Hep-G2 cells was prepared by the acid guanidinium-phenolchloroform (AGPC) method.?

The biopsy material, about $2 \mathrm{~mm}^{3}$, was snap frozen in liquid nitrogen (and stored at $-70^{\circ} \mathrm{C}$ ) then transferred to a $1.5 \mathrm{ml}$ microcentrifuge tube (an Eppendorf tube) containing $150 \mu$ l of disruption buffer ( $4 \mathrm{M}$ guanidinium isothiocyanate, $25 \mathrm{mM}$ sodium citrate $\mathrm{pH} 7$, and $0.5 \%$ sarkosyl (BDH Ltd, UK)) and hand homogenised, after which a further $850 \mu \mathrm{l}$ of disruption buffer was added and the homogenate split into two Eppendorf tubes. Cells were directly harvested from the culture plates using $1 \mathrm{ml}$ of disruption buffer.

Sequentially, for the tissue homogenate, $33 \mu \mathrm{l}$ of $3 \mathrm{M}$ sodium acetate $\mathrm{pH} 5,500 \mu \mathrm{l}$ of phenol (water saturated), and $100 \mu \mathrm{l}$ chloroformisoamyl alcohol (49:1) were added to each Eppendorf with mixing after the addition of each reagent. The final suspension was vortexed for 10 seconds and cooled on ice for 15 minutes. The sample was then centrifuged at $13000 \times \mathrm{g}$ for 15 minutes at $4^{\circ} \mathrm{C}$ after which the aqueous phase containing the RNA was transferred to new Eppendorf tubes and $500 \mu \mathrm{l}$ isopropanol was added. The samples were then stood for not less than one hour at $-70^{\circ} \mathrm{C}$ and the precipitated RNA centrifuged at $13000 \times g$ for 15 minutes at $4^{\circ} \mathrm{C}$. The resultant RNA pellet was resuspended in $150 \mu \mathrm{l}$ of disruption buffer and the two fractions pooled in one tube and precipitated 
with one volume of isopropanol at $-70^{\circ} \mathrm{C}$ for one hour. After centrifugation for 15 minues at $4^{\circ} \mathrm{C}$ the pellet was air dried and resuspended in $20 \mu \mathrm{l}$ of diethyl pyrocarbonate (Sigma Chemical Co, Ltd, Poole, UK) treated water. The concentration of RNA was measured spectrophotometrically at $260 \mathrm{~nm}$ and its purity assessed by the 260:280 $\mathrm{nm}$ ratio.

PREPARATION OF PRIMERS SPECIFIC FOR THE ANDROGEN RECEPTOR AND FOR THE INTERNAL STANDARD SEQUENCE $\beta$-ACTIN

The sequences of the primers for androgen receptor were determined from the human androgen receptor mRNA sequence published by Govindin et al. ${ }^{4}$

Primer 1: ${ }^{5}$ AGC AAC CTT CAC AGC CGC AG ${ }^{3}$ Primer 2: ' GCT GCT GCT GCC TTC GGA TA ${ }^{3}$

The sequences of the primers for $\beta$-actin were determined from the human $\beta$-actin mRNA sequence published by Ponte et al. ${ }^{8}$

Primer 1: "'ATG ATG ATA TCG CCG CGC TC ${ }^{3 \prime}$ Primer 2: 'GCG CTC GGT GAG GAT CTT CA ${ }^{3}$

The primers for both androgen receptor and $\beta$-actin were commercially synthesised by either the Molecular Medicine Unit, King's College, London or Oswell DNA Service, Department of Chemistry, University of Edinburgh, Scotland.

\section{COMPLENTARY DNA (CDNA) SYNTHESIS}

Total RNA $(5 \mu \mathrm{g})$ was heat denatured at $95 \%$ for five minutes then chilled on ice for two minutes. The denatured RNA was added to a reverse transcription mixture (RTm) containing $4 \mu \mathrm{l}$ of $5 \times$ RT buffer (250 mM TRIS-HCl pH 8.3, 375 $\mathrm{mM} \mathrm{KCl}, 50 \mathrm{mM}$ dithiothreitol, $15 \mathrm{mM} \mathrm{MgCl}_{2}$; Gibco BRL), $1 \mu$ l of RNasin ribonuclease inhibitor (30 units/ $\mu$ l; Promega), $2 \mu \mathrm{l}$ of $5 \mathrm{mM}$ deoxy-nucleotide triphosphate mixture (dNTP) (Pharmacia), $1 \mu \mathrm{l}$ of oligo $(\mathrm{dT})_{12-18}(0 \cdot 16 \mu \mathrm{g} / \mu \mathrm{l}$; Pharmacia), and 200 units of $M-M L V$ reverse transcriptase (M-MLV RT; Gibco BRL) in a final volume of $20 \mu \mathrm{l}$. After gentle mixing the RTm was incubated at $37^{\circ} \mathrm{C}$ for 40 minutes another 200 units of M-MLV RT was added and the $\mathrm{RTm}$ again incubated at $37^{\circ} \mathrm{C}$ for 40 minutes. The cDNA/RNA mixture was stored at $-20^{\circ} \mathrm{C}$.

\section{POLYMERASE CHAIN REACTION}

The cDNA/RNA mixture, made from $5 \mu \mathrm{g}$ of RNA, was made up to a final volume of $50 \mu \mathrm{l}$, which would give an original RNA concentration of $0 \cdot 1 \mu \mathrm{g} / \mu \mathrm{l}$. PCR was carried out with $3 \mu \mathrm{l}$ of cDNA (derived from $0.3 \mu \mathrm{g}$ RNA), $2 \cdot 5 \mu \mathrm{l}$ of $10 \times$ PCR buffer (100 mM TRIS-HCl pH 9, $500 \mathrm{mM} \mathrm{KCl}, 20 \mathrm{mM} \mathrm{MgCl} 2,0 \cdot 1 \%$ gelatin wt/vol $1 \%$ Triton X-100; Promega), $12 \cdot 5 \mathrm{pmol}$ of each of the four primers, $1 \mu \mathrm{l}$ of $5 \mathrm{mM}$ dNTP's (Pharmacia), 3 units of Taq polymerase (Promega), and $2 \mu \mathrm{Ci}$ of $\left[\alpha^{32} \mathrm{P}\right] \mathrm{dCTP}$ in a final reaction volume of $25 \mu \mathrm{l}$. The PCR mixture was mixed gently and centrifuged for one second, after which the mixture was overlaid with $100 \mu \mathrm{l}$ of mineral oil and PCR performed in a Perkin Elmer Cetus thermal cycler for 30 cycles. Each
PCR cycle consisted of template denaturation at $94^{\circ} \mathrm{C}$ for one minute, one minute of primer annealing at $65^{\circ} \mathrm{C}$, and three minutes extension/ synthesis at $72^{\circ} \mathrm{C}$.

As a negative control to identify genomic contamination, RNA from each sample was used as a template in the PCR. To show that PCR reactants were free from contamination, two other control PCR reactions were used, one contained only primers and no template DNA, and the other contained only template DNA and no primers.

\section{ELECTROPHORESIS}

PCR products were separated by electrophoresis through a $3 \%$ TRIS-borate (TBE) $(89 \mathrm{mM}$ TRIS-HCl, $89 \mathrm{mM}$ boric acid, $2 \mathrm{mM}$ EDTA pH 8) polyacrylamide gel in $0.5 \% \mathrm{TBE}$ buffer. The gel was then wrapped in Saranwrap and exposed to Hyperfilm-MP (Amersham International, UK) with intensifying screens (Amersham International, $\mathrm{UK}$ ) at $-70^{\circ} \mathrm{C}$. The film was developed and measurement of the androgen receptor and $\beta$-actin was achieved using a Biorad densitometer with an integrating software package. Standards were visualised by staining the gel with $0.5 \mu \mathrm{g} / \mathrm{ml}$ ethidium bromide for 30 minutes at room temperature. The primers were designed to be intron specific ${ }^{9}$ so that contaminating genomic DNA would produce a larger PCR product than that obtained from the androgen receptor mRNA PCR product.

VERIFICATION OF THE PCR-ANDROGEN RECEPTOR FRAGMENT BY SEQUENCE ANALYSIS

PCR was performed as described previously except that only the primers for androgen receptor were used hence the only product would be the $283 \mathrm{bp}$ androgen receptor sequence (PCRandrogen receptor). The PCR-androgen receptor was separated from the PCR reactants using Magic PCR Preps (Promega Corp UK) and sequenced by the fmol Sequencing System (Promega Corp, UK).

\section{Results}

It was first necessary to standardise the method with appropriate controls. Figure 1 shows presence of androgen receptor and $\beta$-actin in HL-A. To identify any genomic contamination of the PCR product a reaction was performed using HL-A RNA, instead of HL-A CDNA, as the template for each new sample studied. Lack of any bands after PCR (Fig 1, lane 2) showed that there was no detectable genomic contamination. Two other controls were used to show that the reagents were not contaminated, lane 3 contained primers only and lane 4 contained HL-A cDNA but no primers, both gave negative results.

The androgen receptor PCR product was determined using both the sense and anti-sense primers (each $20 \mathrm{bp}$ ) by the fmol Sequencing System. The sequence of the sense and antisense strands showed $100 \%$ similarity with the published androgen receptor sequence ${ }^{4}$ from 


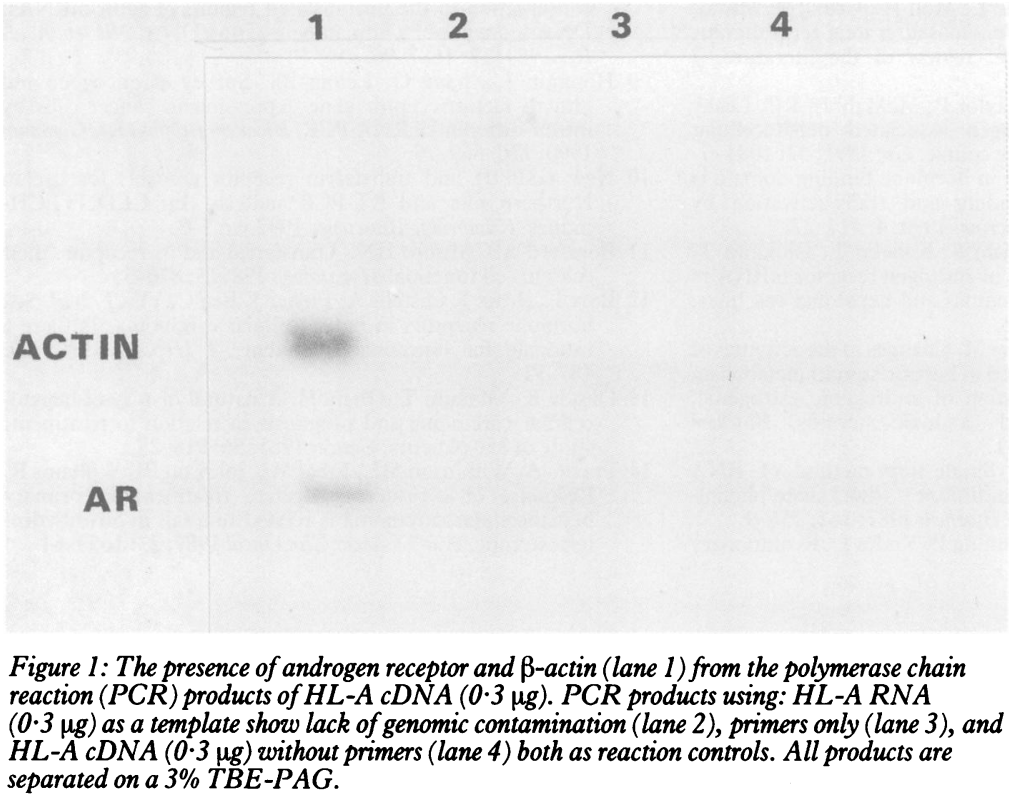

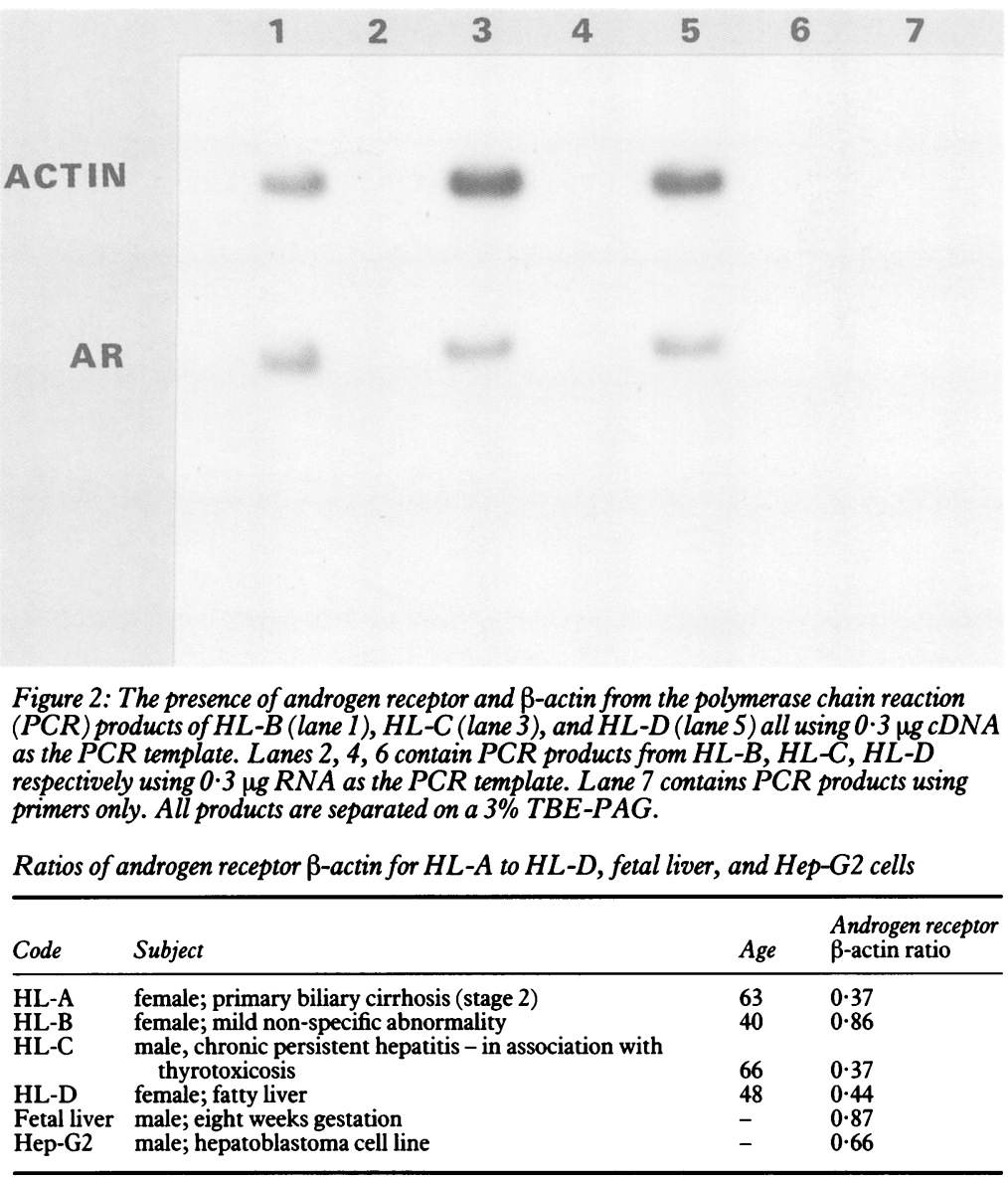

\begin{tabular}{lllll}
\hline ACTIN & 1 & 1 & 2 & \\
AR & & & \\
& ACTIN & & \\
AR &
\end{tabular}

Figure 3: The presence of androgen receptor and $\beta$-actin from the polymerase chain reaction $(P C R)$ products of Hep-G2 (A; lane 1) and fetal liver (B; lane 1) all using $0.3 \mathrm{\mu g} \mathrm{c} / D N A$ as a template for $P C R$. Lanes 2 in both $A$ and $B$ are the $P C R$ products from $H e p-G 2$ and fetal liver respectively using $0 \cdot 3 \mu \mathrm{g} R N A$ as the PCR template. which the primers for androgen receptor were determined.

The presence of androgen receptor was shown in all liver biopsy specimens studied (Figs 1 and 2 ). The expression of androgen receptor is represented at a ratio of androgen receptor: $\beta$ actin when $\beta$-actin is used as the control 'gene expression'. The Table shows the androgen receptor: $\beta$-actin ratios for HL-A to HL-D.

Figure 3 shows the presence of androgen receptor expression in fetal liver and Hep-G2 cells and the Table shows the ratios of androgen receptor: $\beta$-actin.

\section{Discussion}

We have quantified for the first time androgen receptor mRNA expression in four liver biopsy specimens (non-cancerous) (HL-A to HL-D), in fetal liver and in Hep-G2 cells. The values of androgen receptor $m R$ NA expressed as androgen receptor: $\beta$-actin ratios in HL-A to HL-D, fetal liver, and Hep-G2 were $0.37,0.86,0.37,0.44$, 0.87 , and 0.66 respectively. As $\beta$-actin is expressed in all tissues it serves as an internal control for gene expression when comparing androgen receptor expression in multiple tissue samples. $\beta$-actin expression was not only used as an internal control but also to reduce the chance of a false negative result due to reaction error. The use of $\beta$-actin expression as an internal control is not without controversy and recently transferrin receptor expression ${ }^{10}$ has been proposed as a reliable alternative. There is some evidence, however, that transferrin receptor gene expression may also vary. ${ }^{11}$

This finding and those of other recent studies have shown that the human liver is an androgen responsive tissue. ${ }^{312}$ The 10 -fold higher incidence of primary liver cancer in humans ${ }^{13}$ and the hepatocarcinogenic potential of anabolic androgens given orally ${ }^{23}$ suggests that androgen receptor mediated mechanisms may be important in the malignant transformation of human hepatocytes.

The present method provides a means of assessing changes in androgen receptor expression which, as ligand binding assays have indicated, may occur during the progression from normal liver, through chronic hepatitis and cirrhosis to hepatocellular carcinoma. Nakagama et $a l^{5}$ showed the presence of androgen receptor mRNA in surgically resected hepatocellular carcinoma tissue and surrounding non-cancerous tissue and in one hepatoma cell line but did not attempt to quantify these results. Once comparative values of androgen receptor expression in hepatocellular carcinoma and normal liver tissue have been shown a theoretical basis may be provided for the use of anti-androgenic therapy in the treatment of the tumour. One pilot study ${ }^{14}$ has lent some support to this hypothesis. There may also be scope for prevention of transformation to hepatocellular carcinoma in 'at risk' patients with cirrhosis through the use of agents that block or inhibit aspects of androgen receptor expression, ligand binding or nuclear interaction.

1 Wilkinson ML. Sex steroids and primary hepatocellular carcinoma. Anticancer Res 1987; 7: 1071-7. 
2 Carrasco D, Prieto M, Pallardo L, Moll JL, Cruz JM, Munoz C, et al. Multiple hepatic adenomas after long-term therapy with testosterone enanthate: review of the literature. $\mathscr{f}$ Hepatol 1985; 1: 573-8.

3 Gleeson D, Newbould MJ, Taylor P, McMahorn RF, Leahy BC, Warnes TW. Androgen associated hepatocellular carcinoma with an aggressive course. Gut 1991; 32: 1084-6.

4 Govindin MV. Specific region in hormone binding domain is essential for hormone binding and trans-activation by human androgen. Mol Endocrinol 1990; 4: 417-27.

5 Nakagama $H$, Gunji T, Ohnishi S, Kaneko T, Ishikawa T, Makino $R$, et al. Expression of andron receptor mRNA in Makino $\mathrm{R}$, et al. Expression of androgen receptor mRNA in human hepatocellular carcinomas and hepatoma cell lines. Hepatology 1991; 14: 99-102.

Lax RE, Baumann P, Schriefers $M$. Changes in the activities of microsomal enzymes involved in hepatic steroid metabolism in the rat after administration of androgenic estrogenic, progestional, anabolic and catatoxic steroids. Biochem Pharmacol 1984; 33: 1235-41

7 Chomczynski P, Sacchi N. Single-step method of RNA isolation by acid guanidinium thiocyanate-phenochloroform extraction. Anal Biochem 1987; 162: 156-9.

8 Ponte P, Ng S-Y, Engel J, Cunning P, Kedes L. Evolutionary conservation in the untranslated regions of actin mRNAs: DNA sequence of a human beta-actin cDNA: Nucleic Acids Res 1984; 12: 1687-96.

9 Hongiun J, Zhang Q, Leung BS. Survey of oncogene and rowth factor/receptor gene expression in cancer cells by intron-differential RNA/PCR. Biochem Biophys Res Commun 1990; 170: 569-75.

10 New G3PDH and transferrin receptor controls for use in Northern blot and RT-PCR analysis. In: CLONTECH niques. Cambridge Bioscience 1992; vi: 1-3.

11 Bomford AB, Munro HN. Transferrin and its receptor: their roles in cell function. Hepatology $1985 ; 5: 870-5$.

12 Boix L, Bruix J, Castells A, Fuster J, Bru C, Visa J, et al. Sex hormone receptors in hepatocellular carcinoma. Is there a rationale for hormonal treatment? $\mathcal{f}$ Hepatol 1993; 17: rationale

13 Okuda K, Ohtsuki T, Obata H. A natural history of hepatocellular carcinoma and prognosis in relation to treatment: study of 850 patients. Cancer 1985; 56: 918-28.

14 Forbes A, Wilkinson ML, Iqbal MJ, Johnson PJ, Williams R. Response of cyproterone acetate treatment in primary hepatocellular carcinoma is related to a fall in 5 $\alpha$-dihydrotestosterone. Eurf Cancer Clin Oncol 1987; 23: 1659-64. 